NR 19 (28)

BIBLIOTEKA

2015 PL ISSN 1506-3615

$\begin{array}{lllllllllllllllll}M & \text { I } & S & \text { C } & \text { E } & \text { L } & \text { L } & \text { A } & \text { N } & \text { E } & \text { A }\end{array}$

RADOSŁAW FRANCZAK

Instytut Historii, Uniwersytet im. Adama Mickiewicza w Poznaniu

MICHAŁ MURASZKO

Archiwum Archidiecezjalne w Gnieźnie

\title{
Oprawy ksiąg biskupa warmińskiego Szymona Rudnickiego w zbiorach dawnej Biblioteki Katedralnej w Gnieźnie
}

STReSzczenie. Artykuł prezentuje oprawy czterech ksiąg należących do biblioteki biskupa warmińskiego Szymona Rudnickiego, które znajdują się obecnie w Archiwum Archidiecezjalnym w Gnieźnie. Trzy spośród nich zostały sporządzone w jednym, lokalnym warsztacie introligatorskim. Na każdej z omawianych opraw znajduje się superekslibris właściwy hierarchy. W tekście przedstawiono dwa rodzaje superekslibrisów duchownego, które mogą wskazywać na jego bibliofilskie zamiłowania.

SŁowa Kluczowe: Szymon Rudnicki, Archiwum Archidiecezjalne w Gnieźnie, starodruki, introligatorstwo, oprawy, tegumentologia, superekslibris.

Prowadzona pod kierunkiem dra Piotra Pokory (Uniwersytet im. Adama Mickiewicza w Poznaniu) inwentaryzacja zasobu dawnej Biblioteki Katedralnej w Gnieźnie pozwoliła na identyfikację czterech woluminów należących do księgozbioru Szymona Rudnickiego'. Urodził się on w 1552 roku. Studiował w Krakowie, Padwie, Rzymie oraz Bolonii. Był między innymi scholastykiem łęczyckim, kanonikiem krakowskim i warmińskim. Związany z kancelarią królewska, doszedł do urzędu sekretarza wielkiego koronnego. W 1604 roku został biskupem warmińskim. Zmarł 4 lipca 1621 roku².

${ }^{1}$ Projekt grantowy „Inwentaryzacja zasobu Biblioteki Katedralnej w Gnieźnie” finansowany jest z Narodowego Programu Rozwoju Humanistyki MNiSW (nr: $11 \mathrm{H}$ 120179 81).

2 Por. T. Oracki, Słownik biograficzny Warmii, Mazur i Powiśla, Warszawa 1963, s. 247-248; H. Kowalska, Rudnicki Szymon, w: Polski słownik biograficzny, t. 32, Wrocław 
Niewiele wiadomo o zbiorach książkowych warmińskiego hierarchy. W literaturze przedmiotu podano informację, że miał on między innymi nabyć druki należące pierwotnie do biskupa warmińskiego i kardynała Andrzeja Batorego. Jakaś część biblioteki Szymona Rudnickiego stała się własnością kolegium jezuitów w Braniewie, którego księgozbiór w 1626 roku padł łupem Szwedów ${ }^{3}$. Dla przykładu jeden wolumin z proweniencjami duchownego obecnie jest przechowywany w Bibliotece Wyższego Seminarium Duchownego Metropolii Warmińskiej „Hosianum” w Olsztynie ${ }^{4}$. Inny stanowi aktualnie własność Biblioteki Jagiellońskiej w Krakowie $^{5}$. Przedmiotem niniejszego tekstu będą oprawy czterech ksiąg należących do dawnej biblioteki biskupa, które obecnie znajdują się w Archiwum Archidiecezjalnym w Gnieźnie ${ }^{6}$.

Trzy oprawy zabezpieczaja, wydrukowane w 1593 roku w Wenecji, trzytomowe dzieło prawnicze autorstwa Giuseppe Mascardiego ${ }^{7}$. Pochodzą one niewątpliwie z jednego warsztatu introligatorskiego. Do ich sporządzenia użyto fazowanych desek bukowych oraz pierwotnie białej lub kremowej skóry. Na dłuższych brzegach okładzin zachowały się pozostałości po parze zapinek mosiężno-skórzanych. Wszystkie zdobienia wykonano za pomocą: strychulca, łłoków, superekslibrisowej plakiety oraz

1989-1991, s. 649-655; S. Achremczyk, R. Marchwiński, J. Przeracki, Poczet biskupów warmińskich, Olsztyn 1994, s. 129-134; D. Bogdan, Rudnicki Szymon, w: Słownik biograficzny Pomorza Nadwiślańskiego, t. 4, Gdańsk 1997, s. 107-108; Poczet biskupów warmińskich, red. S. Achremczyk, Olsztyn 2008, s. 203-222; E. Gigilewicz, Rudnicki Szymon, w: Encyklopedia katolicka, t. 17, Lublin 2012, kol. 548-549.

3 A. Szorc, Kolegium jezuickie w Braniewie i jego księgozbiór 1565-1626, Olsztyn 1998, s. 78, 107-108; J.Z. Lichański, Oprawy książek ze zbiorów Biblioteki Collegium Societatis Iesu w Braniewie. Wstęp do badań, "Rocznik Biblioteki Narodowej” 2006, t. 37/38, s. 219; J. Trypućko, Katalog księgozbioru kolegium jezuitów w Braniewie zachowanego w Bibliotece Uniwersyteckiej w Uppsali, t. 1, Warszawa-Uppsala 2007, s. 78 (autor nie odnotowuje woluminów pochodzących z dawnej biblioteki Szymona Rudnickiego); H. Grabowska, Szwedzi a Polska, czyli o rodzimych księgozbiorach w Bibliotece Uniwersyteckiej w Uppsali, „Biblioteka” 2010, nr 14, s. 111-112.

${ }^{4}$ Por. J. Wojtkowski, Katalog druków XVI wieku Biblioteki Wyższego Seminarium Duchownego Metropolii Warmińskiej "Hosianum" w Olsztynie, Lublin 2012, s. 425, nr 879 oraz s. 504, nr 1058. Za wskazanie tej pozycji oraz inne cenne uwagi autorzy składają podziękowania ks. kan. Tomaszowi Garwolińskiemu.

5 Katalog poloników XVI wieku Biblioteki Jagiellońskiej, t. 2, red. M. Malicki, E. Zwinogrodzka, Kraków 1994, s. 38, nr 1630.

${ }^{6}$ Archiwum Archidiecezjalne Gniezno [dalej: AAG], sygn.: BK2361, BK3034, BK3042, BK3074.

7 AAG, sygn.: BK3034, BK3042, BK3074: G. Mascardi, Conclusiones probationum omnium quae in utroque foro versantur continens, t. 1-3, Wenecja 1593. 
czterech radełek. Zdobienia górnej i dolnej okładziny każdej z opraw opierają się na kompozycji ramowej (il. 1). Zostały one opracowane w technice ślepego i złoconego wycisku (ostatnią z metod udekorowano jedynie zwierciadła). Na dekorację radełkową składają się ornament palmetowo-arkadowy oraz personifikacje cnót oddzielone dekoracją roślinną i tabliczkami z napisami identyfikacyjnymi. Wyciski z kolejnego narzędzia ukazują popiersia okolone stylizowanym, owalnym wieńcem laurowym, które rozdziela ornament kandelabrowo-roślinny. W ramę otaczającą wąskie zwierciadło wkomponowano wycisk radełka prezentujący ornament geometryczny. W jego wewnętrznych narożnikach umieszczono wyciski z łłoka przedstawiające żołądź (znajdują się one również, obok motywu floralnego, w dwóch listwach). Centrum zwierciadła (il. 2) górnej oraz dolnej okładziny zajmuje superekslibris (właściwy) Szymona Rudnickiego $(73 \times 52 \mathrm{~mm})^{8}$. W owalny kartusz herbowy wkomponowano tutaj godło herbu Lis. Powyżej znajduje się kapelusz rangowy ze sznurami i chwostami. Całości dopełniają trzymacze, które przyjęły formę uskrzydlonych aniołów. Postacie te umieszczono na postumentach przedstawiających dwa trytony. Bezpośrednio ponad kartuszem herbowym znajduje się wyobrażenie anielskiej główki. Całość otacza dwustrefowy pierścień. W jego wewnętrzną część wpisano informacje dotyczące właściciela: „SIMON RVDNIZKI D(ei) G(ratia) EPISCOPVS WARMIENSIS". Natomiast zewnętrzna część przedstawia wieniec laurowy z przewiązkami na osiach ${ }^{9}$.

Szymon Rudnicki występuje na prezentowanym superekslibrisie jako biskup warmiński. Można zatem założyć, że narzędzie, za pomocą którego wyciśnięto znak własnościowy, powstało najwcześniej w 1604 roku. Datę tę należy również przyjąć za terminus a quo wykonania trzech

${ }^{8} \mathrm{Na}$ temat superekslibrisu właściwego zob. K. Piekarski, Książka w Polsce XV i XVI wieku, w: Kultura staropolska, Kraków 1932, s. 380-381; idem, O superexlibrisie polskim, w: Katalog wystawy pięknej książi polskiej urządzonej z powodu IV. Zjazdu Bibliotekarzy Polskich w Warszawie, 31 maja-15 czerwca, Warszawa 1936, s. 29-31; M. Sipayłł, Polskie superexlibrisy XVI-XVIII wieku w zbiorach Biblioteki Uniwersyteckiej w Warszawie, Warszawa 1988, s. 6-8; A. Wagner, Historyczno-artystyczny warsztat historyka ksiażki w badaniach nad nowożytnym introligatorstwem, w: Bibliologia. Problemy badawcze nauk humanistycznych, red. D. Kuźmina, Warszawa 2007, s. 117-118; idem, Superekslibris biskupa ołomunieckiego Stanisława Pawłowskiego. Z badań nad ksiażkowymi znakami własnościowymi polskiej szlachty w XVI wieku, w: Książka w życiu Kościoła. Zbiór studiów, red. T. Kruszewski, Toruń 2009, s. 89, p. 19.

${ }^{9} \mathrm{Na}$ temat herbu Szymona Rudnickiego zob. E. Gigilewicz, Herby biskupów warmińskich, Lublin 2001, s. 107-108; R. Kostecki, Kartusz herbowy Szymona Rudnickiego (1552-1621), biskupa warmińskiego, z katedry we Fromborku, „Rocznik Polskiego Towarzystwa Heraldycznego nowej serii" 2003, t. 6, s. 109-112. 


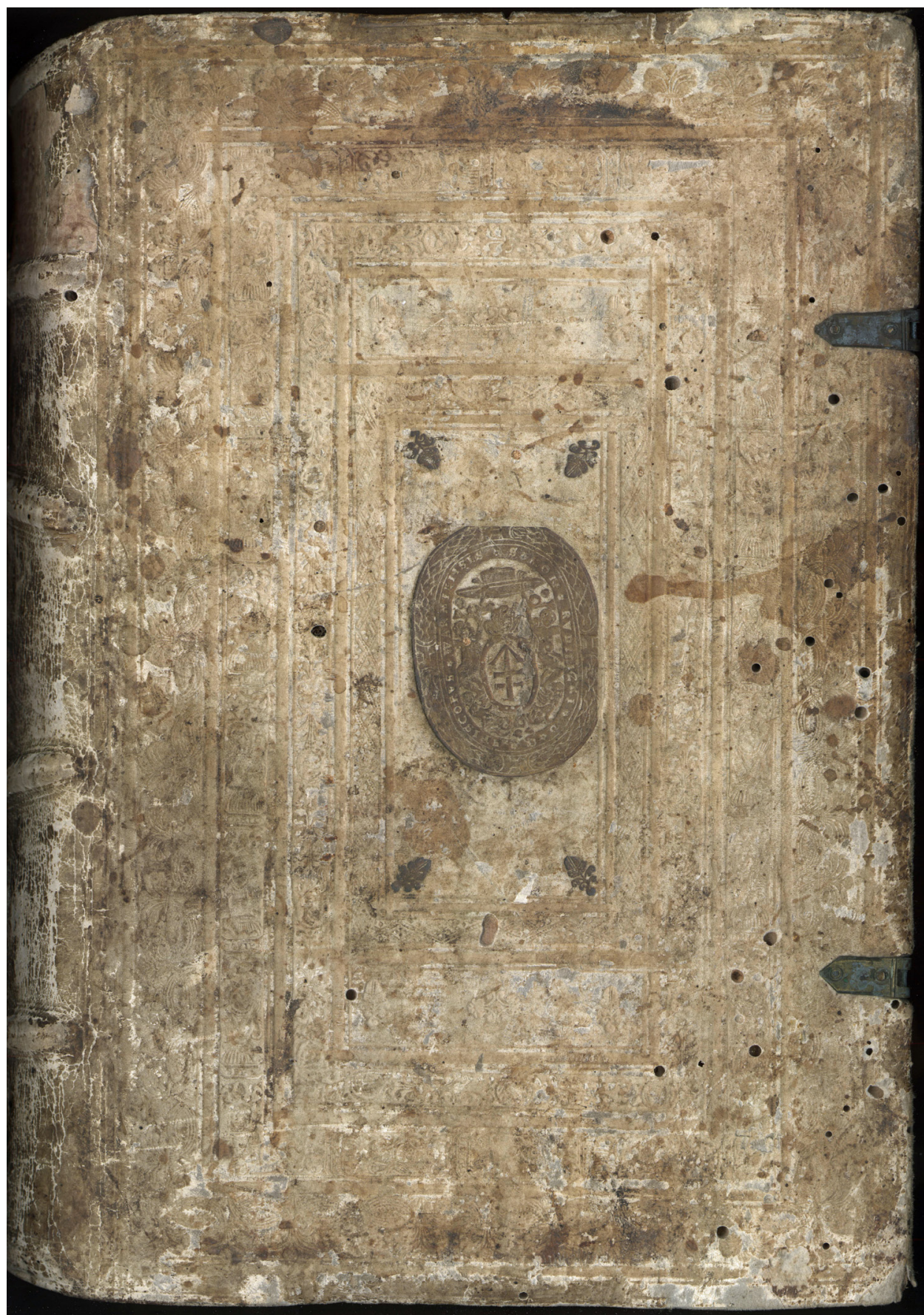

Il. 1. Górna okładzina oprawy starodruku z 1593 roku

Źródło: Archiwum Archidiecezjalne w Gnieźnie, sygn. BK3074. Fot. Mikołaj Macioszek. 


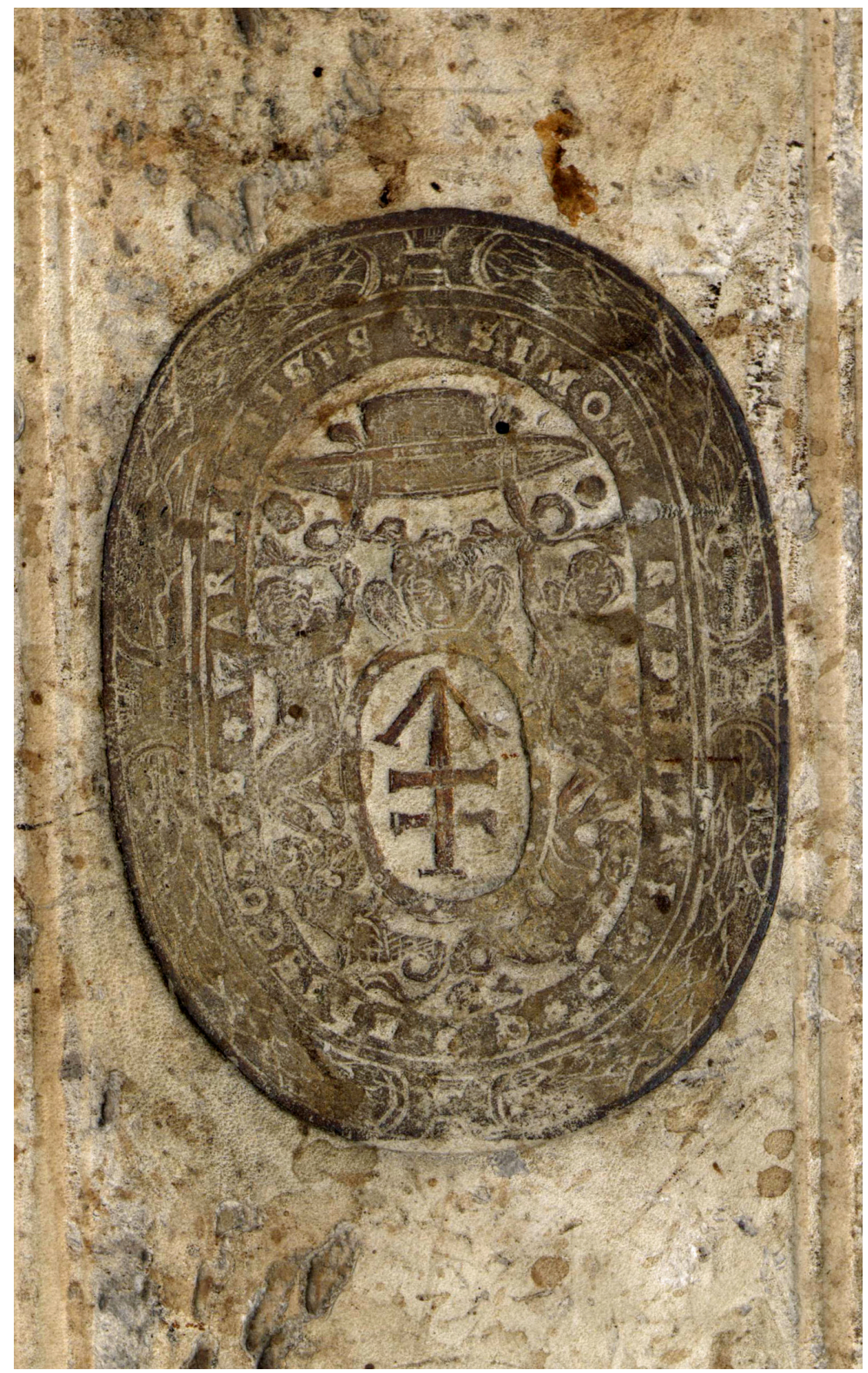

Il. 2. Superekslibris Szymona Rudnickiego na oprawie starodruku z 1593 roku Źródło: Archiwum Archidiecezjalne w Gnieźnie, sygn. BK3074. Fot. Mikołaj Macioszek. 
prezentowanych opraw. Znaki wodne znajdujące się na wyklejkach woluminów przedstawiają flądrę okoloną pierścieniem, w który wpisano imię i nazwisko papiernika: „HENRICH BREPSLY”. Młyn posługujący się tym filigranem należy łączyć z Gdańskiem lub Straszynem ${ }^{10}$. Można zatem założyć, że omawiane oprawy pochodzą z warsztatu introligatora działającego na obszarze Prus ${ }^{11}$.

Na przedniej wyklejce każdej z trzech ksiagg umieszczono niemal jednakowo brzmiące wpisy proweniencyjne: „Ecclesiae Parochialis Borkoviensis in Decanatu Stawiszynensi"12. Pochodzą one najprawdopodobniej z XVII/XVIII stulecia oraz wskazują na wtórnego właściciela woluminów, którym była parafia w Borkowie Starym koło Kalisza. W jaki sposób omawiane książki znalazły się w tym miejscu? Można przypuszczać, że stało się to dzięki jednemu z następców Szymona Rudnickiego na warmińskiej stolicy biskupiej. Był nim Mikołaj Szyszkowski (zm. 1643), urodzony $\mathrm{w}$ podkaliskim Borkowie ${ }^{13}$, w rodzinie od pokoleń związanej właśnie $\mathrm{z}$ tą miejscowością ${ }^{14}$. Być może to on, dysponując przynajmniej kilkoma księgami należącymi pierwotnie do Szymona Rudnickiego, postanowił przekazać je wielkopolskiej parafii. Za przedstawioną hipotezą przemawia także proweniencja monstrancji, która znalazła się w borkowskim kościele za sprawą wspomnianego hierarchy. Umieszczone na niej inicjały oraz

${ }^{10}$ Por. J. Siniarska-Czaplicka, Filigrany papierni położonych na obszarze Rzeczypospolitej Polskiej od początku XVI do połowy XVIII wieku, Wrocław 1969, s. 21; eadem, Papier druków oficyn gdańskich i toruńskich XVI i XVII w., „Roczniki Biblioteczne” 1974, t. 18, z. 1-2, s. 288-289.

11 Przypisanie znaku wodnego z wyklejki danego woluminu do konkretnej papierni może pomóc w określeniu ośrodka introligatorskiego, z którego pochodzi jego oprawa; por. A. Wagner, Introligatorstwo poznańskie XVI wieku jako historyczno-artystyczna terra incognita, w: Sztuka w Wielkopolsce, red. M. Błaszczyński, B. Górecka, M. Górecki, A. Paradowska, Poznań 2013, s. 71.

12 Jak dotąd, poza trzema omawianymi woluminami, zinwentaryzowano dwie księgi (AAG, sygn. BK1413: Henri de Suze, Summa Aurea, Wenecja 1574; BK1446: Bonifacy VIII, Liber sextus decretalium, Rzym 1582) z proweniencjami wskazującymi na parafię w Borkowie Starym.

${ }^{13}$ E. Gigilewicz, Szyszkowski Mikołaj, w: Encyklopedia katolicka, t. 19, Lublin 2013, kol. 240.

${ }^{14} \mathrm{Na}$ temat związków Szyszkowskich z Borkowem Starym zob. np. E. Callier, Powiat kaliski w XVI stuleciu. Szkic geograficzno-historyczny, Poznań 1887, s. 10-11; L. Polaszewski, Własność feudalna w województwie kaliskim w XVI wieku, Poznań 1976, s. 34; J. Tomala, Budownictwo obronne powiatu kaliskiego w XIV-XVIII wieku, Poznań 1995, s. 17; S. Małyszko, Majatki wielkopolskie, t. 6: Powiat kaliski, Szreniawa 2000, s. 14; E. Rutkowska, Historia parafii i kościoła pw. św. Andrzeja Apostoła w Borkowie Starym, Borków Stary 2010, s. 10. 


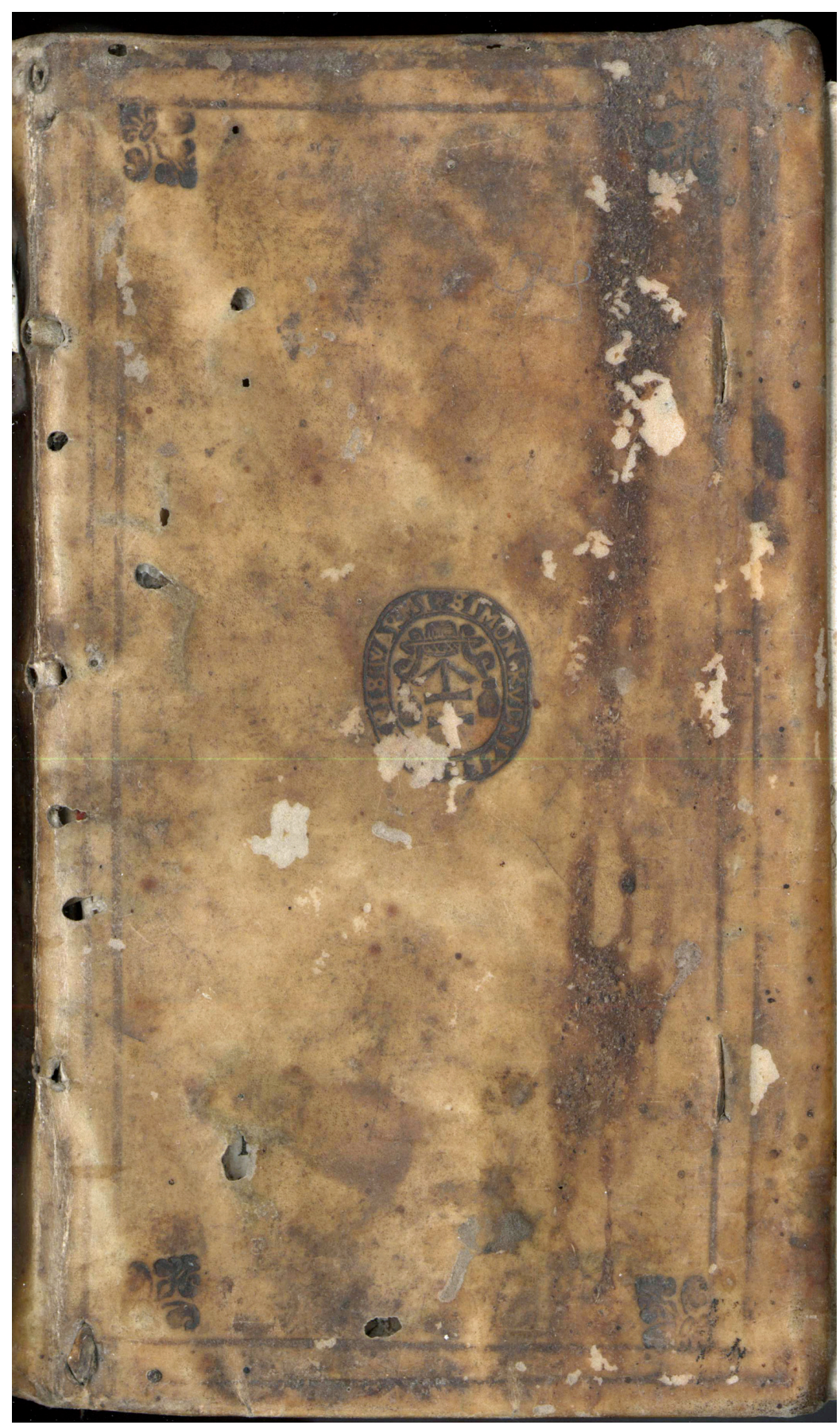

Il. 3. Górna okładzina oprawy starodruku z 1615 roku Źródło: Archiwum Archidiecezjalne w Gnieźnie, sygn. BK2361. Fot. Mikołaj Macioszek. 
herb Ostoja jednoznacznie wskazują na osobę Mikołaja Szyszkowskiego jako jej fundatora ${ }^{15}$.

Wydaje się, że w późniejszym czasie próbowano ukryć noty proweniencyjne dotyczące parafii w Borkowie Starym. Przednie wyklejki, na których umieszczono wpisy, zostały bowiem sklejone $\mathrm{z}$ wewnętrznymi stronami górnych okładzin opraw. W XVIII stuleciu woluminy musiały znajdować się już w bibliotece gnieźnieńskiej kapituły katedralnej. Z tego okresu pochodzą jednakowo brzmiące wpisy proweniencyjne, umieszczone na kartach tytułowych każdego z trzech tomów: „Ex Bibliotheca Reverendissimi Capituli Metropolitani Gnesnensis".

Osobnego omówienia wymaga kolejna $\mathrm{z}$ opraw. Zabezpiecza ona dzieło autorstwa św. Roberta Bellarmina, które ukazało się w 1615 roku $\mathrm{w}$ Toul $^{16}$. Jej okładziny, sporządzone $\mathrm{z}$ drukowanej makulatury introligatorskiej, obłożono pergaminem. Ich zdobienia opracowano $\mathrm{w}$ technice wycisku złoconego. Dekoracja zarówno górnej, jak i dolnej okładziny opiera się na podwójnej, linearnej ramie tworzącej zwierciadło (il. 3). W jego wewnętrznych narożnikach umieszczono wyciski z floralnego tłoka. W centrum zwierciadła znajduje się owalny superekslibris właściwy (21 x $18 \mathrm{~mm}$ ). Przedstawia on godło herbu Lis, ponad którym umieszczono kapelusz rangowy ze sznurami i chwostami. Całość okala pierścień z wpisanymi weń informacjami o właścicielu: „SIMON RVDNIZKI D(ei) G(ratia) EPIS(copus) WARMI(ensis)". Można przyjąć, że oprawę tę sporządzono między 1615 a 1621 rokiem. Trudno stwierdzić, w jaki sposób niniejszy wolumin znalazł się w zbiorach Biblioteki Katedralnej w Gnieźnie. Wpisy proweniencyjne wskazuja, że należał on w późniejszym okresie także do brata zakonnego Jana Bartochowskiego oraz do Pawła Smoczyńskiego (obydwaj skądinąd bliżej nieznani) ${ }^{17}$.

Niewykluczone, że dalsze prace inwentaryzacyjne prowadzone w dawnej Bibliotece Katedralnej pozwolą na odkrycie kolejnych ksiąg należących do zbiorów Szymona Rudnickiego. Jednak już ten szczątkowy wycinek dawnej biblioteki hierarchy wskazuje na jego bibliofilskie zamiłowania. Dowodnie przemawiają za tym dwa zaprezentowane superekslibrisy (właściwe). Warto przy tym odnotować, że duchowny, jako biskup warmiński, korzystał z usług przynajmniej jednej lokalnej intro-

${ }^{15}$ Katalog zabytków sztuki w Polsce, t. 5: Województwo poznańskie, red. T. Ruszczyńska, A. Sławska, z. 6: Powiat kaliski, oprac. T. Ruszczyńska, A. Sławska, Z. Winiarz, Warszawa 1960, s. 3; A. Jabłońska-Ważny, S. Przygodzki, A. Roth, J.A. Splitt, Z dziejów gminy Żelazków, Kalisz 1998, s. 29; E. Rutkowska, op.cit., s. 47-49.

${ }^{16}$ AAG, sygn. BK2361: R. Bellarmin, De ascensione mentis in Deum, Toul 1615.

17 Proweniencje te mają następujące brzmienie: „Fr Joannes Bartochowski P. C. 6 grossis” oraz „ex libris Pauli Smoczynski”. 
ligatorni. Odtworzenie bardziej precyzyjnego itinerarium zaprezentowanych ksiąg Szymona Rudnickiego umożliwią w przyszłości być może dalsze badania nad jego księgozbiorem, w tym odkrycie kolejnych woluminów wskazujących na przynależność do omawianej kolekcji.

\section{Bibliografia}

Źródła

Archiwum Archidiecezjalne Gniezno, sygn.: BK1413, BK1446, BK2361, BK3034, BK3042, BK3074.

Opracowania

Achremczyk S., Marchwiński R., Przeracki J., Poczet biskupów warmińskich, Olsztyn 1994.

Bogdan D., Rudnicki Szymon, w: Słownik biograficzny Pomorza Nadwiślańskiego, t. 4, Gdańsk 1997.

Callier E., Powiat kaliski w XVI stuleciu. Szkic geograficzno-historyczny, Poznań 1887.

Gigilewicz E., Herby biskupów warmińskich, Lublin 2001.

Gigilewicz E., Rudnicki Szymon, w: Encyklopedia katolicka, t. 17, Lublin 2012.

Gigilewicz E., Szyszkowski Mikołaj, w: Encyklopedia katolicka, t. 19, Lublin 2013.

Grabowska H., Szwedzi a Polska, czyli o rodzimych ksiegozbiorach w Bibliotece Uniwersyteckiej w Uppsali, „Biblioteka” 2010, nr 14.

Jabłońska-Ważny A., Przygodzki S., Roth A., Splitt J.A., Z dziejów gminy Żelazków, Kalisz 1998.

Katalog poloników XVI wieku Biblioteki Jagiellońskiej, t. 2, red. M. Malicki, E. Zwinogrodzka, Kraków 1994.

Katalog zabytków sztuki w Polsce, t. 5: Województwo poznańskie, red. T. Ruszczyńska, A. Sławska, z. 6: Powiat kaliski, oprac. T. Ruszczyńska, A. Sławska, Z. Winiarz, Warszawa 1960.

Kostecki R., Kartusz herbowy Szymona Rudnickiego (1552-1621), biskupa warmińskiego, z katedry we Fromborku, „Rocznik Polskiego Towarzystwa Heraldycznego nowej serii" 2003, t. 6.

Kowalska H., Rudnicki Szymon, w: Polski słownik biograficzny, t. 32, Wrocław 1989-1991.

Lichański J.Z., Oprawy książek ze zbiorów Biblioteki Collegium Societatis Iesu w Braniewie. Wstẹp do badań, „Rocznik Biblioteki Narodowej” 2006, t. 37/38.

Małyszko S., Majatki wielkopolskie, t. 6: Powiat kaliski, Szreniawa 2000.

Oracki T., Słownik biograficzny Warmii, Mazur i Powiśla, Warszawa 1963.

Piekarski K., Ksiażka w Polsce XV i XVI wieku, w: Kultura staropolska, Kraków 1932.

Piekarski K., O superexlibrisie polskim, w: Katalog wystawy pięknej książki polskiej urzadzonej z powodu IV. Zjazdu Bibliotekarzy Polskich w Warszawie, 31 maja-15 czerwca, Warszawa 1936.

Poczet biskupów warmińskich, red. S. Achremczyk, Olsztyn 2008. 
Polaszewski L., Własność feudalna w województwie kaliskim w XVI wieku, Poznań 1976.

Rutkowska E., Historia parafii i kościoła pw. św. Andrzeja Apostoła w Borkowie Starym, Borków Stary 2010.

Siniarska-Czaplicka J., Filigrany papierni położonych na obszarze Rzeczypospolitej Polskiej od poczatku XVI do połowy XVIII wieku, Wrocław 1969.

Siniarska-Czaplicka J., Papier druków oficyn gdańskich i toruńskich XVI i XVII w., „Roczniki Biblioteczne” 1974, t. 18, z. 1-2.

Sipayłło M., Polskie superexlibrisy XVI-XVIII wieku w zbiorach Biblioteki Uniwersyteckiej w Warszawie, Warszawa 1988.

Szorc A., Kolegium jezuickie w Braniewie i jego księgozbiór 1565-1626, Olsztyn 1998.

Tomala J., Budownictwo obronne powiatu kaliskiego w XIV-XVIII wieku, Poznań 1995.

Trypućko J., Katalog księgozbioru kolegium jezuitów w Braniewie zachowanego w Bibliotece Uniwersyteckiej w Uppsali, t. 1, Warszawa-Uppsala 2007.

Wagner A., Historyczno-artystyczny warsztat historyka ksiażki w badaniach nad nowożytnym introligatorstwem, w: Bibliologia. Problemy badawcze nauk humanistycznych, red. D. Kuźmina, Warszawa 2007.

Wagner A., Introligatorstwo poznańskie XVI wieku jako historyczno-artystyczna terra incognita, w: Sztuka w Wielkopolsce, red. M. Błaszczyński, B. Górecka, M. Górecki, A. Paradowska, Poznań 2013.

Wagner A., Superekslibris biskupa ołomunieckiego Stanisława Pawłowskiego. Z badań nad ksiażkowymi znakami własnościowymi polskiej szlachty w XVI wieku, w: Ksiażka w życiu Kościoła. Zbiór studiów, red. T. Kruszewski, Toruń 2009.

Wojtkowski J., Katalog druków XVI wieku Biblioteki Wyższego Seminarium Duchownego Metropolii Warmińskiej „Hosianum” w Olsztynie, Lublin 2012.

\section{RADOSŁAW FRANCZAK, MICHAŁ MURASZKO}

\section{The bindings of the books of Szymon Rudnicki, the Bishop of Warmia, in the collection of former Cathedral Library in Gniezno}

Aвstract. This article discusses the bindings of a set of four books that once formed part of the library of Szymon Rudnicki, the Bishop of Warmia, and are currently kept in the Archdiocesan Archive in Gniezno. Three bindings from this set were made in a single, local bindery workshop. Each of the discussed bindings bears the supralibros indicating the ownership of the book. The article presents two types of the supralibros of the bishop that may indicate the latter's bibliophile interests.

Key words: Szymon Rudnicki, Archdiocese Archive in Gniezno, old prints, bookbinding, bindings, tegumentology, supralibros (ownership mark). 